\title{
Recovery Observations from Alkali, Nanoparticles and Polymer Flooding as Combined Processes
}

\author{
Rafael E. Hincapie ${ }^{1, *(\mathbb{D})}$, Ante Borovina ${ }^{1}$, Elisabeth Neubauer ${ }^{1}$, Muhammad Tahir ${ }^{2}{ }^{(\mathbb{D}}$, Samhar Saleh ${ }^{3}{ }^{(D)}$, \\ Vladislav Arekhov ${ }^{1}$, Magdalena Biernat ${ }^{1}$ and Torsten Clemens ${ }^{1}$
}

check for updates

Citation: Hincapie, R.E.; Borovina, A.; Neubauer, E.; Tahir, M.; Saleh, S.; Arekhov, V.; Biernat, M.; Clemens, T. Recovery Observations from Alkali, Nanoparticles and Polymer Flooding as Combined Processes. Polymers 2022, 14, 603. https://doi.org/ $10.3390 /$ polym 14030603

Academic Editor: Norazlianie Sazal

Received: 23 November 2021

Accepted: 31 January 2022

Published: 3 February 2022

Publisher's Note: MDPI stays neutral with regard to jurisdictional claims in published maps and institutional affiliations.

Copyright: (C) 2022 by the authors. Licensee MDPI, Basel, Switzerland. This article is an open access article distributed under the terms and conditions of the Creative Commons Attribution (CC BY) license (https:// creativecommons.org/licenses/by/ $4.0 /)$
1 OMV Exploration \& Production GmbH, OMV Upstream Technology \& Innovation, New Technology, TECH Center \& Lab, 1020 Vienna, Austria; ante.borovina@omv.com (A.B.); elisabeth.neubauer@omv.com (E.N.); vladislav.arekhov@omv.com (V.A.); magdalena.biernat@omv.com (M.B.); torsten.clemens@omv.com (T.C.)

2 Institute of Subsurface Energy Systems, Clausthal University of Technology, Agricolastr. 10, 38678 Clausthal-Zellerfeld, Germany; muhammadtahir04@hotmail.com

3 Montanuniversität Leoben, DPE Department Petroleum Engineering, Franz-Josef-Straße 18, 8700 Leoben, Austria; samhar@outlook.de

* Correspondence: rafaeleduardo.hincapiereina@omv.com
Abstract: We have studied wettability alterations through imbibition/flooding and their synergy with interfacial tension (IFT) for alkalis, nanoparticles and polymers. Thus, the total acid number (TAN) of oil may determine the wetting-state of the reservoir and influence recovery and IFT. Data obtained demonstrate how the oil TAN number (low and high), chemical agent and reservoir mineralogy influence fluid-fluid and rock-fluid interactions. We used a laboratory evaluation workflow that combines complementary assessments such as spontaneous imbibition tests, IFT, contact angle measurements and selected core floods. The workflow evaluates wettability alteration, IFT changes and recovery when injecting alkalis, nanoparticles and polymers, or a combination of them. Dynamics and mechanisms of imbibition were tracked by analyzing the recovery change with the inverse bond number. Three sandstone types (outcrops) were used, which mainly differed in clay content and permeability. Oils with low and high TANs were used, the latter from the potential field pilot $16 \mathrm{TH}$ reservoir in the Matzen field (Austria). We have investigated and identified some of the conditions leading to increases in recovery rates as well as ultimate recovery by the imbibition of alkali, nanoparticle and polymer aqueous phases. This study presents novel data on the synergy of IFT, contact angle Amott imbibition, and core floods for the chemical processes studied.

Keywords: polymer flooding; alkali-polymer flooding; EOR nanoparticles; interfacial tension; wettability alteration

\section{Introduction}

Enhanced oil recovery (EOR) methods promote fluid-fluid (F-F) and rock-fluid (R-F) interactions due to the injection of external agents not initially present in the reservoir [1,2]. Fluid-fluid interactions define static as well as dynamic interfacial properties at the oilbrine-system interface, considering the possible chemical interactions taking place [3-8]. Moreover, rock-fluid interactions could result not only in wettability alterations [8-14], but also in fine migration, often leading to permeability changes [15,16], and other possible mechanisms related to the transport in porous media. The main contributions of both F-F and R-F on additional oil recovery remain subject to study, especially when hybrid processes are applied/evaluated.

Data in the literature show that oil production from chemical EOR has increased over the last decade. For instance, polymer EOR has been implemented in numerous fields, as reported by Delamaide et al. [17], Zhu [18], Kumar et al. [19], Anand et al. [20] and Sieberer et al. [21]. Nevertheless, only a few chemical floods involving the injection of more complex chemical agent systems such as alkali, surfactants or co-solvents, in addition to 
polymers, have been applied at field scale, as reported by Watson et al. [22], Yin et al. [23], Pitts et al. [24] and Delamaide [25].

Polymer flooding is a widely used and commercially accepted chemical EOR (cEOR) technology $[2,26,27]$. Polymers increase the viscosity of the aqueous phase and subsequently improve the displacement efficiency due to their favorable mobility ratio. Generally, most researchers believe that polymers do not contribute to enhancing oil recovery, but assist in increasing the ultimate recovery [28]. Some others propose that polymers can contribute to EOR by improving the sweep efficiency $[29,30]$. Lately, polymers have been used in synergetic applications with other cEOR techniques such as alkali and/or nanoparticle injection seeking to improve R-F/F-F interactions [18,31-37]. For instance, added alkali/nanoparticles will trigger R-F/F-F interactions, and polymers are expected to contribute as mobility controllers helping recover additional oil due to its better displacement [26,38-43].

Alkali flooding is also a proven technology often applied in combination with polymers or surfactants. Alkalis react with the acidic polar compounds present in oil and promote/enhance the generation of in situ soaps (saponify organic acids) $[34,44]$. This reaction also leads to decreasing IFT at the oil-brine interface. IFT reduction is the result of F-F interactions, causing an increase in the capillary number, hence reducing the residual oil saturation. Capillary number, which relates viscous and capillary forces, is strongly influenced by the IFT and contact angle (wettability alteration) [45]. The roles of both IFT and wettability alterations have been reported in the literature, not only for alkali, but for a combination of cEOR processes [1,44,46-52]. However, both remain as continuous topics of research when it comes to understanding and designing $c E O R$ applications.

Nanoparticles (NPs) have recently been in the oil industry's spotlight, showing good outcomes in multiple scientific fields. Improved EOR processes are an NP application area in upstream business. In a nutshell, NPs are expected to promote R-F interactions, leading to oil mobilization; hence, the additional recovery. Different mechanisms have been proposed to explain NP effects in the reservoir, such as IFT reduction, wettability alteration or disjoining pressure, among others [53]. Much research in recent years has shown the NP effects on interfacial tension (F-F interactions) [46,49,54-60]. However, wettability alterations through NPs are controlled by various factors, such as NP concentration, hydrophobicity, the nature of the reservoir and the NPs [45].

It is generally accepted that one approach to assess wettability alterations during cEOR processes is by performing laboratory test/measurements. Such evaluations include contact angle, spontaneous and force imbibition as a way to validate or understand the changes taking place. Multiple variables play a key role on the evaluations, such as brine/oil composition, the type of chemicals and rock types. For example, some NPs could be more efficient in light oil, whereas others work better in heavy oil [56,58-60]. Therefore, the total acid number (TAN) could be another parameter affecting the R-F/F-F interactions during EOR processes. Some researchers also refer to the saponifiable number (SN), and saponifiable acids, as a more reliable comparative variable [61]. TAN defines the number of polar compounds, whereas SN refers to the amount of those compounds able to become soap. In general, acids are also known as surface active agents, composed of naphthenic acid and asphaltenes. Naphthenic acids (cycloaliphatic carboxylic group) are responsible for the oil-wet state of the reservoir rock [4,62]. Moreover, asphaltenes are reported to influence interfacial properties at the oil-brine interface [7,63-65]. Therefore, based on the surface-active agent activity, oils with high TAN/SN ratios are good candidates for the synergistic applications of polymers, alkalis and nanoparticles [44].

Synergistic applications of EOR technologies have been reported in the literature with promising results. A compilation of studies assessing the potential and cost-effective synergies of EOR methods is presented in Table 1. Synergies of alkali, nanoparticle and polymer flooding might be promising for excessive oil recovery due to different contributions of each recovery process. Alkalis promote in situ soap generation when reacting with polar compounds of the oil. The saponification process should lower the interfacial tension and 
could also influence wettability to some extent. The process could be enhanced by NPs due to their reported effects on wettability alterations and lowering the IFT. Furthermore, the presence of polymers will enhance the oil recovery due to good mobility control (improved displacement). The proposed alkali, nanoparticle and polymer synergy differs from conventional ASP flooding due to the dual activity (IFT reduction and wettability alteration) of NPs compared with surfactants (only IFT reductions). Furthermore, the commercial cost/number of surfactants and their limitations to chemical loss (adsorption) at field scale under reservoir conditions have promoted the potential of NPs instead.

Table 1. Selected literature and evaluations of the synergy of alkali/nanoparticles/polymer as cost-effective EOR applications.

\begin{tabular}{|c|c|c|c|c|c|}
\hline Synergy & $\begin{array}{c}\text { Reported Recovery } \\
\text { Mechanisms }\end{array}$ & Interaction & Media & Main Focus & Ref. \\
\hline NPs, P, A & $\begin{array}{c}\text { Increase in viscosity + reduction } \\
\text { in IFT }\end{array}$ & $\mathrm{R}-\mathrm{F}$ and $\mathrm{F}-\mathrm{F}$ & Micromodel & $\begin{array}{l}\text { Contact angle (CA, } \\
\text { polymer adsorption }\end{array}$ & [66] \\
\hline NPs, P & $\begin{array}{l}\text { Increase in polymer viscosity, } \\
\text { low polymer adsorption, } \\
\text { homogenous NPs dispersion }\end{array}$ & $\mathrm{R}-\mathrm{F}$ and $\mathrm{F}-\mathrm{F}$ & $\begin{array}{l}\text { Water-wet } \\
\text { micromodels }\end{array}$ & $\begin{array}{l}\text { IFT, CA and nano size } \\
\text { distribution }\end{array}$ & [67] \\
\hline NPs, P & $\begin{array}{l}\text { Higher polymer viscoelasticity, } \\
\text { low polymer retention and } \\
\text { capillary forces reduction }\end{array}$ & $\mathrm{R}-\mathrm{F}$ and $\mathrm{F}-\mathrm{F}$ & Sandpacks & $\begin{array}{l}\text { IFT, contact angle, RRF, } \\
\text { viscosity, and relative } \\
\text { permeability curves }\end{array}$ & [68] \\
\hline $\mathrm{A}, \mathrm{P}, \mathrm{S}, \mathrm{NPs}, \mathrm{F}$ & $\begin{array}{l}\text { Review summary of IFT, } \\
\text { polymer adsorption, } \\
\text { viscoelasticity, mobility control, } \\
\text { wettability alteration, emulsion } \\
\text { stabilization, }\end{array}$ & $\mathrm{R}-\mathrm{F}$ and $\mathrm{F}-\mathrm{F}$ & $\begin{array}{l}\text { Laboratory to } \\
\text { field applications }\end{array}$ & $\begin{array}{l}\text { Review paper covering } \\
\text { technical challenges and } \\
\text { possible remediations, } \\
\text { field projects. }\end{array}$ & [69] \\
\hline $\mathrm{A}, \mathrm{P}$ & $\begin{array}{l}\text { IFT reduction and wettability } \\
\text { alteration }\end{array}$ & $\mathrm{R}-\mathrm{F} \& \mathrm{~F}-\mathrm{F}$ & $\begin{array}{c}\text { Sandstone cores } \\
\text { (oil-wet, } \\
\text { water-wet) }\end{array}$ & $\begin{array}{l}\text { Spontaneous imbibition, } \\
\text { IFT, contact angle, oil TAN } \\
\text { value }\end{array}$ & [1] \\
\hline $\begin{array}{l}\text { NPs-P, NPs-S, } \\
\text { NPs-S-P }\end{array}$ & $\begin{array}{l}\text { Review on IFT reduction \& } \\
\text { wettability alteration }\end{array}$ & $\mathrm{R}-\mathrm{F}$ and $\mathrm{F}-\mathrm{F}$ & $\begin{array}{l}\text { Laboratory to } \\
\text { field applications }\end{array}$ & $\begin{array}{l}\text { Review paper covering } \\
\text { nanotechnology } \\
\text { applications in chemical } \\
\text { EOR }\end{array}$ & [70] \\
\hline NPs, P, S & $\begin{array}{l}\text { IFT reduction, improved } \\
\text { rheological properties and } \\
\text { wettability alteration }\end{array}$ & $\mathrm{R}-\mathrm{F}$ and $\mathrm{F}-\mathrm{F}$ & $\begin{array}{l}\text { Laboratory to } \\
\text { field applications }\end{array}$ & $\begin{array}{l}\text { Review on } \\
\text { nanotechnology in EOR, } \\
\text { challenges, and future } \\
\text { research }\end{array}$ & [71] \\
\hline NPs, P & $\begin{array}{l}\text { Improving viscosity and } \\
\text { thermal stability of HPAM } \\
\text { polymer }\end{array}$ & NA & $\begin{array}{l}\text { Laboratory to } \\
\text { field applications }\end{array}$ & $\begin{array}{c}\text { Review on } \\
\text { nanotechnology for } \\
\text { improving viscosity and } \\
\text { stability }\end{array}$ & [72] \\
\hline NPs, A & $\begin{array}{l}\text { IFT reduction and wettability } \\
\text { alteration }\end{array}$ & $\mathrm{R}-\mathrm{F}$ and $\mathrm{F}-\mathrm{F}$ & $\begin{array}{l}\text { Sandstone core } \\
\text { plugs }\end{array}$ & $\begin{array}{l}\text { Spontaneous imbibition, } \\
\text { IFT tests and phase } \\
\text { behavior }\end{array}$ & [49] \\
\hline NPs-P & $\begin{array}{l}\text { IFT reduction, in situ emulsion } \\
\text { generation, microscopic flow } \\
\text { and wettability alteration }\end{array}$ & $\mathrm{R}-\mathrm{F}$ and $\mathrm{F}-\mathrm{F}$ & $\begin{array}{l}\text { Neutral-wet core } \\
\text { plugs }\end{array}$ & $\begin{array}{l}\text { Flooding experiments, IFT, } \\
\text { imbibition tests focusing } \\
\text { on pressure and recovery }\end{array}$ & [73] \\
\hline A, NPs, P & $\begin{array}{l}\text { NPs as emulsion stabilizers in } \\
\text { AP. IFT and phase behavior. } \\
\text { Wettability alteration. }\end{array}$ & $\mathrm{R}-\mathrm{F}$ and $\mathrm{F}-\mathrm{F}$ & $\begin{array}{l}\text { Sandstone } \\
\text { outcrops }\end{array}$ & $\begin{array}{l}\text { Flooding experiments, IFT, } \\
\text { imbibition tests focusing } \\
\text { on pressure and recovery }\end{array}$ & {$[46,47]$} \\
\hline
\end{tabular}


In this study, we investigate the dynamics of wettability alterations by integrating different data sources. The results presented here aim show that the workflow can be used as an efficient screening tool to determine the effectiveness of various substances to increase the oil recovery rate and ultimate recovery. Moreover, the workflow helps to understand the synergistic effects of alkalis, nanoparticles and polymer flooding.

\section{Overall Approach}

To screen injection agents that provide the best synergistic recovery and understand their dynamics using a workflow, the steps presented Figure 1 were undertaken.

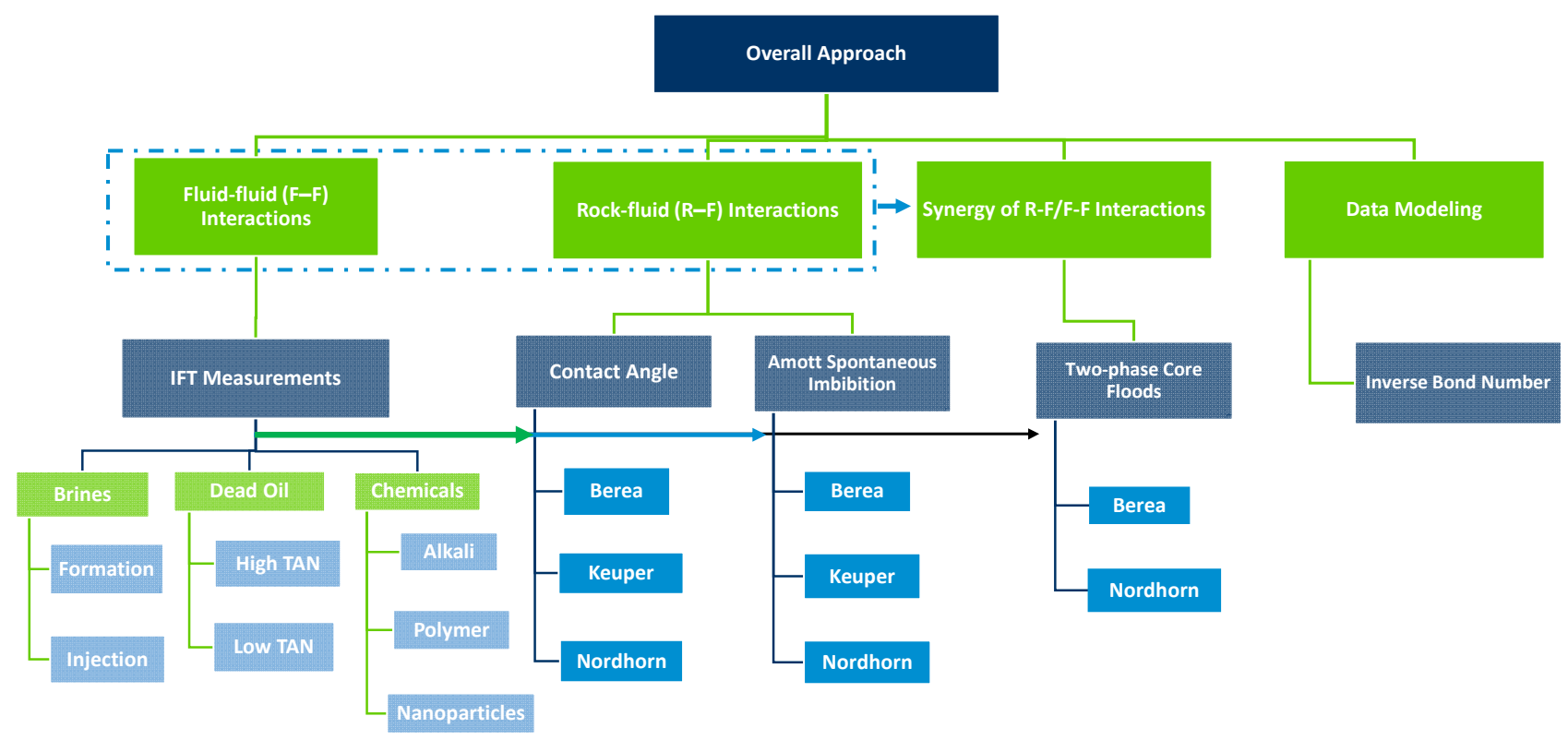

Figure 1. Workflow adopted for the evaluations presented in this paper. The approach incorporates various laboratory evaluations and cross analyses of the data.

\section{Materials and Methods}

\subsection{Synthetic Brines}

For a potential field pilot, it is foreseen to use water produced from the reservoir as injection fluid (softened). Therefore, to mimic the salt content and the buffered behavior of reservoir water, the composition of the injection water (hereafter, test water, TW) included $18.96 \mathrm{~g} / \mathrm{L} \mathrm{NaCl}$ and $1.85 \mathrm{~g} / \mathrm{L} \mathrm{NaHCO}_{3}$ with a $\mathrm{pH}$ of $8.93 \pm 0.01$ and density of $0.994 \mathrm{~g} / \mathrm{cm}^{3}$, both measured at $23^{\circ} \mathrm{C}$. The formation brine was composed of $19.79 \mathrm{~g} / \mathrm{L} \mathrm{NaCl}, 0.40 \mathrm{~g} / \mathrm{L}$

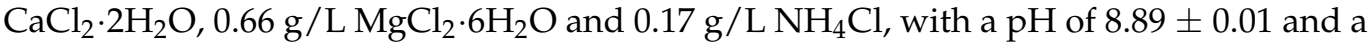
density of $0.995 \mathrm{~g} / \mathrm{cm} 3$.

\subsection{Crude Oils}

We used oil samples from the 16 TH reservoir of Matzen field (Austria, well Bo-112) and St. Ulrich reservoir (Well StU 65). With the different total acid number (TAN) in both oils, the main aim was to define its impact on the recovery process. The $16 \mathrm{TH}$ oil was more acidic in nature than St Ulrilch oil (TAN $=1.61 \mathrm{mg} / \mathrm{KOH} / \mathrm{g}$ oil for $16 \mathrm{TH}$ vs. $0.39 \mathrm{mg}$ $\mathrm{KOH} / \mathrm{g}$ oil for StU); therefore, it was expected to promote more oil wetness. Properties of the crude oil samples are listed in Table 2. 
Table 2. Composition of crude oils used in this study.

\begin{tabular}{ccc}
\hline Property & High TAN & Low TAN \\
\hline Reservoir/Well & 16 TH/Bockfliess 112 & St. Ulrich/St.U. 65 \\
TVD top [m] & 1622 & 1060 \\
TAN [mg KOH/g] & 1.61 & 0.39 \\
Saturates [\%] & 39 & 55 \\
Aromatics [\%] & 20 & 25.6 \\
Resins $[\%]$ & 39 & 18.6 \\
Asphaltene $[\%]$ & 2 & 0.8 \\
Saponifiable Acids $[\mu \mathrm{mol} / \mathrm{g}]$ & 26 & n.m. \\
$\mu @ 60^{\circ} \mathrm{C}[\mathrm{mPa} . \mathrm{s}]$ & 11.9 & 6 \\
$\rho$ @ $20^{\circ} \mathrm{C} / 60^{\circ} \mathrm{C}\left[\mathrm{g} / \mathrm{cm}^{3}\right]$ & $0.917 / 0.884$ & $0.866 / 0.842$ \\
\hline n.m. $=$ not measured. & &
\end{tabular}

\subsection{Alkali, Polymer and Nanoparticles}

Considering cost and to prevent the formation of silica scales in the production wells due to the dissolution of rock minerals [74,75], $\mathrm{Na}_{2} \mathrm{CO}_{3}$ was investigated here. A known polyacrylamide (HPAM) was used as the polymer: FP3630S, at a concentration of $2000 \mathrm{ppm}$. For the nanomaterials, four different types were used, mainly silica-coated particles. Further details and specific characterizations of the nanomaterials can be found in Saleh et al. [49] and Neubauer et al. [46,47].

\subsection{Outcrop Samples}

The main properties of the three evaluated sandstone outcrops are presented in Table 3. Berea is a yellowish-grey sandstone that consists of very homogeneous, well-sorted sand comprising, on average, $90 \%$ quartz, $4 \%$ feldspar, and approximately $6 \%$ clays (mainly kaolinite with small contributions of illite and chlorite). Quantities lower than $1 \%$ are found for calcite, siderite, and pyrite. Nordhorn is a Bentheimer-like outcrop defined as a fine-medium-grained porous sandstone that consists of $96.6 \%$ quartz, $0.9 \%$ potassium feldspar and $2.5 \%$ kaolinite. Keuper sandstone is a well-sorted arenite containing $97 \%$ quartz, $3 \%$ clays, $<1 \%$ plagioclase and calcite, with a particular reddish color given by the iron oxides covering the mineral grains. Further information on the outcrops used in this study can be found in our previous publications: Saleh et al. [49]; Arekhov et al. [1]; and Neubauer et al. [46]. In order to assure consistent rock surface properties, new core plugs were used for each measurement.

\subsection{Interfacial Tension (IFT) Evaluations}

Interfacial tension (IFT) evaluations were performed between different EOR fluids and high-/low-TAN oil in order to investigate the effect. The IFT was measured using a spinning drop tensiometer (SDT) manufactured by Krüss GmbH (Hamburg, Germany). All measurements were conducted at reservoir temperature $\left(60^{\circ} \mathrm{C}\right)$ using a rotational speed of $7000 \mathrm{rpm}$ throughout the $300 \mathrm{~min}$ testing time, with a time interval of $20 \mathrm{~s}$ between readings.

\subsection{Amott Spontaneous Imbibition Experiments}

Amott spontaneous imbibition experiments were performed using Amott cells, with the oil-saturated cores submerged in the displacing fluid. Oil production was tracked over time by recording the volumes in the pipes at the top of the cells. Experiments were performed at $60^{\circ} \mathrm{C}$ and in duplicates or triplicates. Notably, spontaneous imbibition data have not been corrected for oil thermal expansion. Cores were stored for 3 weeks in an oven at $60^{\circ} \mathrm{C}$ after being saturated with oil for aging purposes. 
Table 3. Overall core and saturation data for the outcrop samples used in this study.

\begin{tabular}{|c|c|c|c|c|c|c|c|}
\hline \multirow{2}{*}{ Parameter } & \multirow{2}{*}{ Units } & \multicolumn{2}{|c|}{ Berea $^{1}$} & \multicolumn{2}{|c|}{ Keuper $^{2}$} & \multicolumn{2}{|c|}{$\begin{array}{c}\text { Nordhorn } \\
\text { (Bentheimer) }^{3}\end{array}$} \\
\hline & & Mean & $\mathrm{SD}^{*}$ & Mean & $\mathrm{SD}^{*}$ & Mean & $\mathrm{SD}^{*}$ \\
\hline Length & \multirow{2}{*}{$\mathrm{cm}$} & 6.97 & 0.02 & 8.12 & 0.09 & 8.01 & 0.11 \\
\hline Diameter & & 2.96 & 0.01 & 2.98 & 0.01 & 2.96 & 0.01 \\
\hline Bulk Volume & \multirow{2}{*}{$\mathrm{cm}^{3}$} & 47.76 & 0.26 & 55.76 & 0.73 & 54.42 & 0.87 \\
\hline Pore Volume & & 10.77 & 0.19 & 12.75 & 0.22 & 13.07 & 0.26 \\
\hline Grain Volume & $\mathrm{kg} / \mathrm{cm}^{3}$ & 37.00 & 0.31 & 42.98 & 0.67 & 41.36 & 0.70 \\
\hline Porosity & $\%$ & 22.60 & 0.40 & 23.30 & 0.80 & 23.96 & 0.35 \\
\hline$N_{2}$ permeability $\left(k_{g}\right)$ & \multirow[b]{2}{*}{$\mathrm{mD}$} & 447.60 & 37.40 & 1425.20 & 349.60 & 2313.02 & 162.10 \\
\hline $\begin{array}{l}\text { Water (Test Water) } \\
\text { permeability }\left(k_{w}\right)\end{array}$ & & 223.90 & 17.90 & 890.00 & 193.90 & 1501.00 & 190.12 \\
\hline $\begin{array}{l}\text { Irreducible water } \\
\text { saturation }\end{array}$ & $\%$ & 24.00 & 8.00 & 21.40 & 7.90 & 25.60 & 4.00 \\
\hline
\end{tabular}

${ }^{1}$ Data from 68 core plugs. ${ }^{2}$ Data from 41 core plugs. ${ }^{3}$ Data from 26 core plugs. SD ${ }^{*}=$ standard deviation.

\subsection{Contact Angle Experiments}

Contact angle experiments were performed with selected samples using a low-pressure and high-temperature view cell 2 bar (LPCA 202011) in a setup designed by HOT Microfluidics GmbH (Goslar, Germany). Prior to the measurements, cleaned and polished core plugs were aged at atmospheric pressure and at $60^{\circ} \mathrm{C}$ for six weeks. A Labotron (LDP 4) pump (Labtron Equipment Ltd. Surrey, UK) was connected to the inlet of the cell to inject the aqueous phase. Pressure exertion occurred at the bottom of the view cell. A capillary was connected to the inlet which dispensed oil for analysis of the contact angle. The cell was exposed to a light source to ensure a high-contrast image. The camera constantly recorded the gathered images from the other side of the cell. Additional information of the setup and testing conditions were presented by Arekhov et al. [1].

\subsection{Two-Phase Core Floods}

Details on the experimental setup are presented in Schumi et al. [44]. Cores were scanned for inhomogeneities and then filled with the TW brine. Cores were stored for 3 weeks in an oven at $60^{\circ} \mathrm{C}$ after being saturated with $16 \mathrm{TH}$ oil for aging purposes. The core was mounted vertically and flooded from bottom to top. The injection rate was set to $2 \mathrm{~mL} / \mathrm{h}$, corresponding to a frontal velocity of $1 \mathrm{ft} / \mathrm{d}$. Overall, two pore volumes (PVs) of the EOR slug were injected in each experiment. Notably, we compared the selected experiments, because not all were covered in this section. First, cores were flooded with around 1.5 PV of water (brine) until no additional oil was produced. Then, the injection rate was increased to $10 \mathrm{~cm}^{3} / \mathrm{h}$ to ensure that limited mobile oil was left in the core.

\subsection{Inverse Bond Number Modeling}

After spontaneous imbibition tests, data were interpreted using bond number calculations, as described in Schechter et al. [48]. The evaluation uses core and fluid properties in order to delineate the main imbibition mechanisms: capillary or gravity.

$$
N_{B}^{-1}=C \frac{\sigma \sqrt{\Phi / k}}{\Delta \rho g H}
$$

where $N_{B}{ }^{-1}$ is the inverse bond number (dimensionless), $C$ is a constant (0.4 for the capillary tube model), $\sigma$ is the interfacial tension $(\mathrm{N} / \mathrm{m}), \Phi$ is the porosity (fraction), $k$ is the 
permeability $\left(\mathrm{m}^{2}\right), \Delta \rho$ is the phase density difference $\left(\mathrm{kg} / \mathrm{m}^{3}\right), g$ is gravity $\left(\mathrm{m} / \mathrm{s}^{2}\right)$, and $H$ is the core height in the Amott cell (m).

\subsection{Post Spontaneous Amott Imbibition Test-Rock Property Evaluation}

Dean-Stark and Soxhlet extractions were used to clean the cores. The water and oil were removed by toluene in Dean-Stark apparatus, followed by Soxhlet extraction with methanol to remove salts. Subsequently measurements of porosity and permeability to gas were performed.

\section{Results and Discussion}

\subsection{Interfacial Tension (IFT) Evaluations}

In Table 4, we present a comparison of the IFT values obtained for the fluids discussed in this study. Data are shown comparing high- and low-TAN oil IFTs at two specific reference points. Initial IFT refers to the initial measurement period between elapse times of 10 and $20 \mathrm{~min}$ (square root $=\sim 3.5$ ). Equilibrium IFT refers to the value after sufficient interaction time and the value is no longer changing mostly found for a period around 900 min (square root $=\sim 30$ ). In agreement with AlGeer et al. [76], for some cases, a distinct variation is observed between initial and equilibrium IFT values. We attribute the values obtained for the baseline brine to the effect of the buffer capacity of $\mathrm{NaHCO}_{3}$. The obtained values are lower than those typically reported for oil-brine systems $(\sim 20 \mathrm{mN} / \mathrm{m})$. An overall observation for both oil cases is that the initial and equilibrium IFT barely changed for the three fluids. This is the case for baseline (brine, TW), nanoparticles only and polymers, all dissolved in test water (TW). As reported by Saleh et al. [49], nanomaterials as standalone EOR agents do not lead to remarkable changes in IFT in high-/low-TAN oil. Similarly, as reported by Yin et al. [23], and Arekhov et al. [1], the polymer had a minimal effect on IFT.

Table 4. Summary of IFT values of various oil/brine systems in this study.

\begin{tabular}{|c|c|c|c|c|c|c|c|c|c|}
\hline \multirow{3}{*}{ Fluid } & \multirow{3}{*}{$\begin{array}{c}\text { Viscosity } \\
{[\mathrm{mPa} . \mathrm{s}]} \\
60^{\circ} \mathrm{C} \\
7.984 \mathrm{~s}^{-1}\end{array}$} & \multicolumn{4}{|c|}{ High-TAN Oil, [mN/m] } & \multicolumn{4}{|c|}{ Low-TAN Oil, [mN/m] } \\
\hline & & \multicolumn{2}{|c|}{ Initial IFT } & \multicolumn{2}{|c|}{ Equilibrium IFT } & \multicolumn{2}{|c|}{ Initial IFT } & \multicolumn{2}{|c|}{ Equilibrium IFT } \\
\hline & & Mean & SD * & Mean & SD * & Mean & SD * & Mean & SD * \\
\hline Baseline-Brine (TW) & 0.571 & 7.84 & 0.43 & 8.40 & 0.50 & 4.31 & 0.62 & 3.40 & 0.56 \\
\hline NPs only in TW ${ }^{1}$ & 5.325 & 3.67 & 0.20 & 3.75 & 0.20 & 2.02 & 0.18 & 1.29 & 0.01 \\
\hline $\begin{array}{l}\text { Alkali }(3000 \text { ppm } \\
\left.\mathrm{Na}_{2} \mathrm{CO}_{3}\right) \text { in TW }\end{array}$ & 0.559 & 0.41 & 0.62 & 0.11 & 0.07 & 0.70 & 0.28 & 0.55 & 0.15 \\
\hline $\begin{array}{l}\text { Alkali }(7000 \mathrm{ppm} \\
\left.\mathrm{Na}_{2} \mathrm{CO}_{3}\right) \text { in TW }\end{array}$ & 0.601 & 0.87 & 0.19 & 0.07 & 0.01 & 0.34 & 0.11 & 0.48 & 0.18 \\
\hline $\begin{array}{l}\text { NPs with } 3000 \mathrm{ppm} \\
\mathrm{Na}_{2} \mathrm{CO}_{3} \text { in TW }\end{array}$ & 7.254 & 0.27 & 0.02 & 0.095 & 0.01 & 0.775 & 0.04 & 0.585 & 0.01 \\
\hline $\begin{array}{c}\text { Polymer (SNF } 3630 \text { S) } \\
\text { in TW }\end{array}$ & 19.536 & 3.31 & 0.25 & 3.61 & 0.36 & 4.03 & 0.37 & 4.50 & 0.22 \\
\hline $\begin{array}{c}7000 \text { ppm Na } \mathrm{Na}_{3} \text { with } \\
\text { SNF } 3630 \mathrm{~S} \text { in TW }\end{array}$ & 18.054 & 2.41 & 0.55 & 0.04 & 0.01 & 0.48 & 0.09 & 0.78 & 0.18 \\
\hline
\end{tabular}

${ }^{1}$ Average of three nanomaterials at $0.1 \% \mathrm{wt}$. and 15 measurements each. $\mathrm{SD}^{*}=$ standard deviation.

For the high-TAN oil, the effect of the alkali solutions on IFT was clear. Alkali (3000 ppm) in TW achieved a 3.7-fold IFT reduction comparing the initial and equilibrium values, whereas for alkali $(7000 \mathrm{ppm})$ in TW, the IFT was reduced 12 -fold. When nanoparticles were used together with alkali and NPs with 3000 ppm $\mathrm{Na}_{2} \mathrm{CO}_{3}$ in TW, the reduction was almost threefold. The IFT reduction is attributed to the adsorption of particles onto the oil-water surface, as reported in the literature (e.g., by Saleh et al. [49], Kamal et al. [53], Moradi et al. [58] and Ershadi et al. [54]). The highest reductions were 
observed with the combination of alkali (7000 ppm $\mathrm{Na}_{2} \mathrm{CO}_{3}$ ) and polymer (SNF $3630 \mathrm{~S}$ ) in TW.

For the low-TAN oil, it was observed that small changes took place when the EOR solutions came into contact with the oil. The main explanation is the lack of saponifiable acids in the oil able to generate soaps. In most cases, the initial IFT was lower than equilibrium, with a variation of 0.7 -fold. Although for nanoparticles together with alkali (3000 ppm) a 1.27-fold decrease was observed, we considered it a neglectable change.

Conclusively, NPs with alkali solution (3000 ppm) yielded the lowest range of initial and equilibrium IFT in both cases, low-TAN, and high-TAN oil. This lower IFT response could be due to the combined chemical interactions of NPs as well as the alkali.

\subsection{Contact Angle Observations}

An overall comparison is presented in Table 1 for the selected samples. For the base case (brine-TW) of Berea and Nordhorn, we observed that the rock remained water-wet despite the aging. The possible reasons could be limited amount of clay in both rock samples as well as the $100 \%$ oil saturation of core plugs. The existing literature supports the hypothesis that a $\mathrm{pH}$ value $\leq 5.5$ of formation brine develops a negatively charged rock surface in sandstone (as shown by Tahir et al. [77]). Moreover, the presence of divalent cations in the formation brine helps to build a bridge between the negatively charged rock surface and polar oil compounds, resulting in alterations in the wettability (oil-wet) during the aging process. However, Keuper shifted to oil-wet in the baseline experiments. A significant amount of clay and the presence of iron oxides in Keuper made this wettability shift possible; even without the formation of brine (lower $\mathrm{pH}$ value and divalent cations). Conclusively, the aging process of Keuper plugs altered the rock surface, which changed from hydrophilic to hydrophobic, resulting in polar oil compounds attaching to the rock surface. Wettability alterations of the Berea and Bentheimer sandstone core plugs through a two- or three-week aging process have also been established by many researchers (such as Tahir et al. [8]), but with the condition of initial brine saturation (divalent cation and lower $\mathrm{pH}$ value). Similarly, we suspect that aging the core plugs in this study changed the wettability to mixed-wet or oil-wet. This is especially the case for Keuper core plugs, as reported by Arekhov et al. [1].

Interestingly, adding chemicals to TW brine (NPs only, alkali only, NPs with alkali or alkali with polymer) showed promising results, changing the wettability of Keuper plugs from oil-wet to water-wet. From Table 5, with the baseline- brine (TW) —-the aged Keuper core plug exhibited strong hydrophobic characteristics with a measured contact angle of $149^{\circ}$. However, the contact angle was decreased for all added chemicals to $\approx 55^{\circ}$, but significantly for NPs, to $31.50^{\circ}$, confirming the change in rock surface to hydrophilic. Hence, wettability alterations could induce polar oil compound detachment and can be seen as additional oil recovery from added chemicals. However, polymers alone cannot develop rock-fluid interactions with a focus on wettability alterations; hence, contact angle measurements with polymer solutions alone were not performed in this study.

From Table 5, we can infer that Keuper core plugs could be the potential core plugs for synergetic EOR mechanisms of IFT reductions, as well as wettability alterations from oil-wet to water-wet system. In contrast, IFT reduction is the main additional recovery mechanism for Berea and Nordhorn, because contact angle measurements confirmed the water-wet condition of both plugs after the aging process. However, the aging process was performed in the absence of any brine formation for these core plugs ( $100 \%$ oil saturation), and the contact angle results differed in the presence of initial brine saturation. 
Table 5. Summary of selected contact angle data expressed in degrees $\left[{ }^{\circ}\right]$ measured at $60{ }^{\circ} \mathrm{C}$. Data were measured at 300 min observation for the fluid samples used in this study.

\begin{tabular}{ccccccc}
\hline \multirow{2}{*}{ Fluid } & \multicolumn{2}{c}{ Berea } & \multicolumn{2}{c}{ Keuper } & \multicolumn{2}{c}{ Nordhorn (Bentheimer) } \\
\cline { 2 - 7 } & High TAN & Low TAN & High TAN & Low TAN & High TAN & Low TAN \\
\hline Baseline-Brine (TW) & 30.00 & n.m. & 149.00 & 60.70 & 58.70 & 60.70 \\
\hline NPs only in TW & 33.50 & n.m. & 31.50 & n.m. & n.m. & n.m. \\
\hline Alkali (3000 ppm Na $\mathrm{CO}_{3}$ ) in TW & 35.01 & n.m. & 55.76 & n.m. & n.m. & n.m. \\
\hline Alkali (7000 ppm Na $\mathrm{CO}_{3}$ ) in TW & n.m. & n.m. & 54.20 & 47.80 & 57.20 & 42.70 \\
\hline NPs with 3000 ppm Na $\mathrm{CO}_{3}$ in TW & 33.20 & n.m. & 46.02 & n.m. & n.m. & n.m. \\
\hline $\begin{array}{c}7000 \text { ppm Na } \mathrm{CO}_{3} \text { with SNF 3630 S } \\
\text { in TW }\end{array}$ & n.m. & n.m. & 56.10 & 55.90 & 57.80 & 59.80 \\
\hline
\end{tabular}

n.m. $=$ not measured; ${ }^{1}$ Average of two nanomaterials.

\subsection{Amott Spontaneous Imbibition Experiments}

Data are presented per rock type and oil; Figures 2-4 show graphical representations of the recoveries obtained, whereas Tables 6 and 7 report comparisons of recovered oil and incremental values per oil and rock type. Different observations can be pointed out:

- Berea: it was observed that combining nanomaterials with alkali leads to the highest incremental oil, as shown in Figure 2. This is explained by acid-alkali reactions and the generation of in situ soaps, as reported by Saleh et al. [49]. The solution also depicted the lowest IFT of the compared group in Figure 2a for the high-TAN oil. Surprisingly, the contributions of each chemical fluid separately were much lower. In contrast, for the low-TAN oil, it was observed that alkali achieved the highest incremental oil recovery, followed by the nanomaterials and then the alkali;

- Keuper: recoveries in this outcrop clearly presented a difference between high- and low-TAN oil, as shown in Figure 3. The highest recoveries were achieved with the combination of nanomaterials and alkali or by alkali alone. In addition to the IFT, the wettability nature of this outcrop (discussed in the contact angle section) helps explain the observations;

- Nordhorn (Bentheimer): it can be observed from Figure 4 that alkali in combination with a polymer on a similar slug leads to the highest incremental recovery in both oils. Observations were reported by Arekhov et al. [1] for the system with similar IFT and oil. The polymer alone did not lead to any further additional recovery greater than $5 \%$, as shown in Tables 6 and 7 ;

- As predicted in the contact angle section, Keuper plugs showed higher additional oil recoveries compared with Berea and Nordhorn core plugs for NPs in alkali chemical systems for both low-TAN and high-TAN oil. This significant additional oil recovery is due to the synergetic effect of NPs and alkali, and resulted in the IFT reduction and wettability alteration from oil-wet to water-wet systems. 


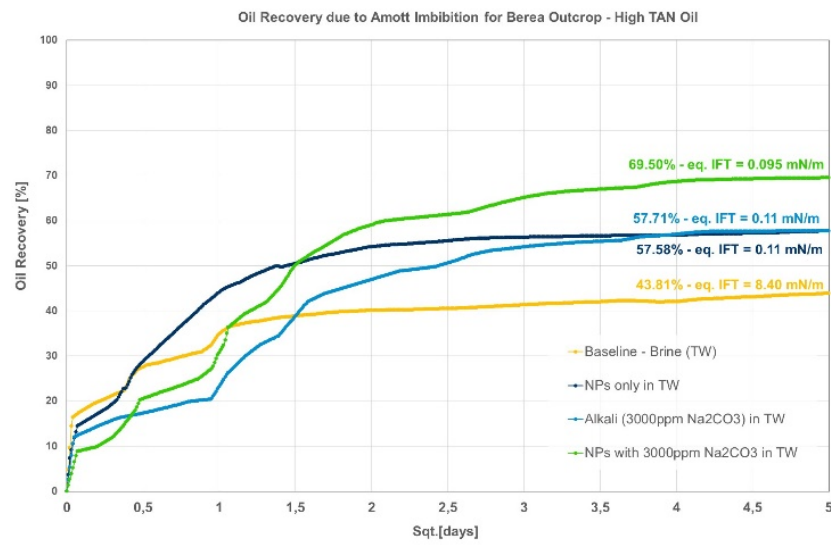

(a) High-TAN oil.

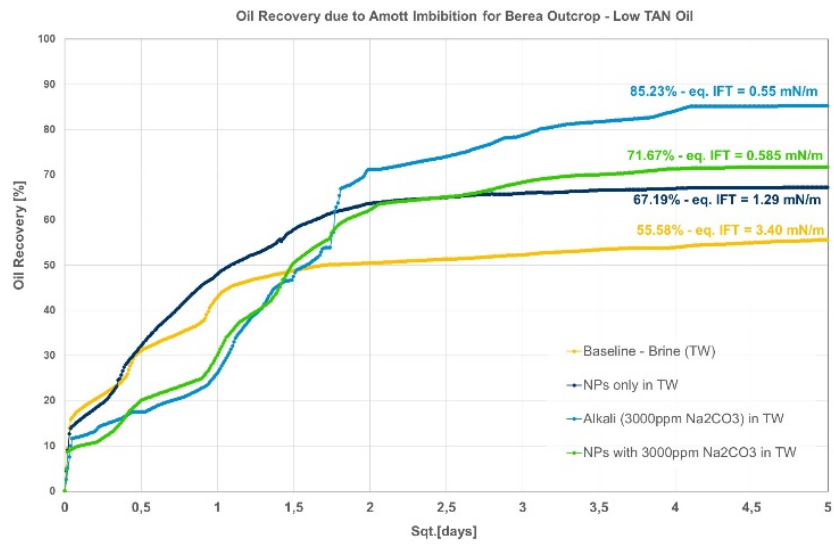

(b) Low-TAN oil.

Figure 2. Amott spontaneous imbibition data for evaluations performed in Berea outcrops. (a) Recoveries obtained for the high-TAN oil; (b) recoveries obtained for the low-TAN oil.

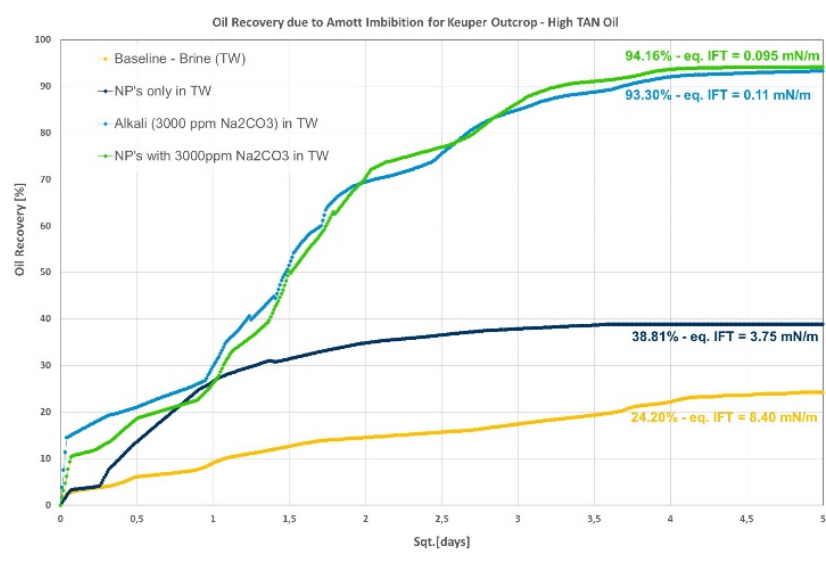

(a) High-TAN oil.

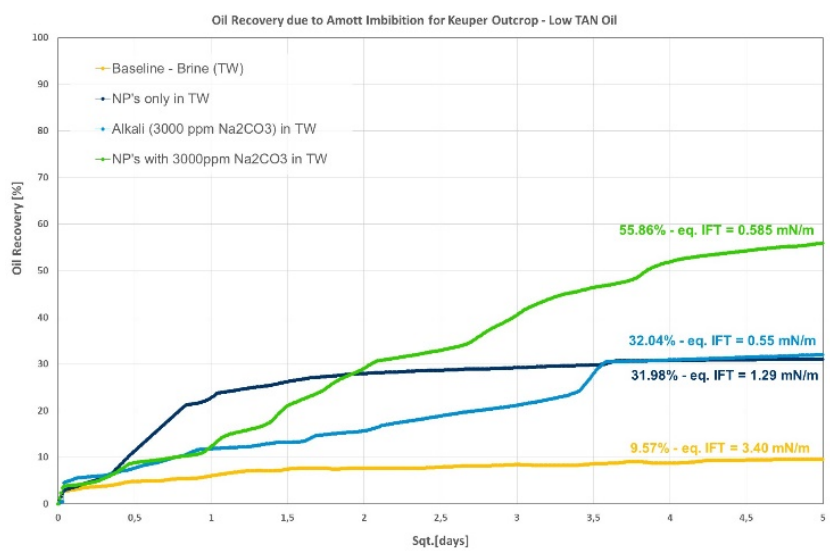

(b) Low-TAN oil.

Figure 3. Amott spontaneous imbibition data for evaluations performed in Keuper outcrops. (a) Recoveries obtained for the high-TAN oil; (b) recoveries obtained for the low-TAN oil.

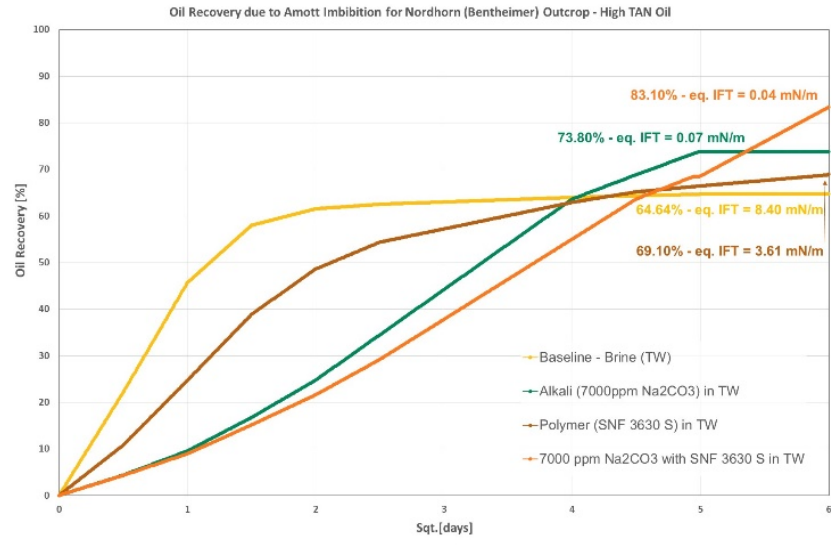

(a) High-TAN oil.

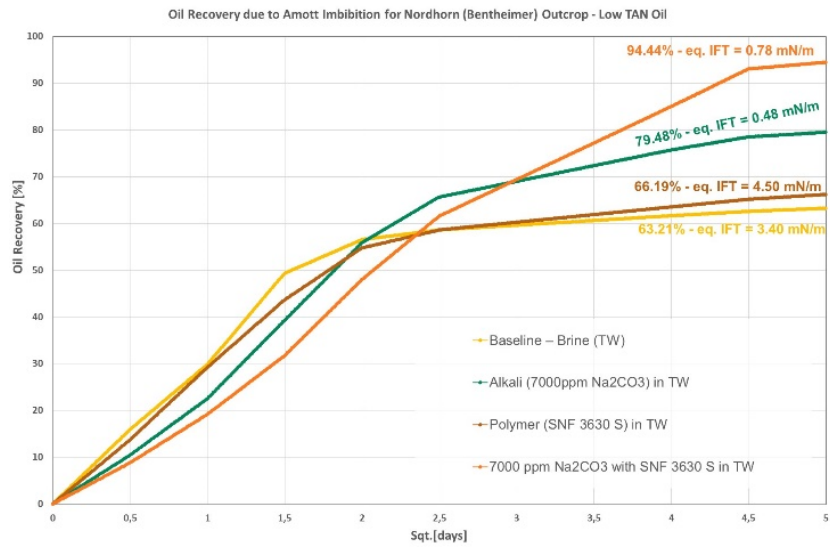

(b) Low-TAN oil.

Figure 4. Amott spontaneous imbibition data for evaluations performed in Nordhorn outcrops. (a) Recoveries obtained for the high-TAN oil; (b) recoveries obtained for the low-TAN oil. 
Table 6. Summary of recoveries [\%] obtained for high-TAN oil during Amott spontaneous imbibition for the fluid samples used in this study.

\begin{tabular}{|c|c|c|c|c|c|c|}
\hline \multirow[t]{2}{*}{ Imbibing Fluid } & \multicolumn{2}{|c|}{ Berea, $[\%]$} & \multicolumn{2}{|c|}{ Keuper, [\%] } & \multicolumn{2}{|c|}{$\begin{array}{c}\text { Nordhorn } \\
\text { (Bentheimer), [\%] }\end{array}$} \\
\hline & R.O & I.O. & R.O & I.O. & R.O & I.O. \\
\hline Baseline-Brine (TW) & 43.81 & - & 24.20 & - & 64.64 & - \\
\hline NPs only in TW ${ }^{1}$ & 57.58 & 13.77 & 38.31 & 14.11 & n.m. & n.m. \\
\hline Alkali (3000 ppm $\mathrm{Na}_{2} \mathrm{CO}_{3}$ ) in TW & 57.71 & 13.90 & 93.30 & 69.10 & n.m. & n.m. \\
\hline Alkali (7000 ppm $\left.\mathrm{Na}_{2} \mathrm{CO}_{3}\right)$ in TW & n.m. & n.m. & n.m. & n.m. & 73.80 & 9.16 \\
\hline NPs with 3000 ppm Na${ }_{2} \mathrm{CO}_{3}$ in TW & 69.50 & 25.69 & 94.16 & 69.96 & n.m. & n.m. \\
\hline Polymer (SNF 3630 S) in TW & n.m. & n.m. & n.m. & n.m. & 69.10 & 4.46 \\
\hline $\begin{array}{c}7000 \text { ppm } \mathrm{Na}_{2} \mathrm{CO}_{3} \text { with SNF } 3630 \mathrm{~S} \\
\text { in TW }\end{array}$ & n.m. & n.m. & n.m. & n.m. & 83.10 & 18.46 \\
\hline
\end{tabular}

n.m. = not measured; ${ }^{1}$ Average of two nanomaterials; R.O. = recovered oil; I.O. = incremental oil (corrected to brine recovery).

Table 7. Summary of recoveries [\%] obtained for low-TAN oil during the Amott spontaneous imbibition for the fluid samples used in this study.

\begin{tabular}{|c|c|c|c|c|c|c|}
\hline \multirow[t]{2}{*}{ Imbibing Fluid } & \multicolumn{2}{|c|}{ Berea, $[\%]$} & \multicolumn{2}{|c|}{ Keuper, [\%] } & \multicolumn{2}{|c|}{$\begin{array}{c}\text { Nordhorn } \\
\text { (Bentheimer), [\%] }\end{array}$} \\
\hline & R.O & I.O. & R.O & I.O. & R.O & I.O. \\
\hline Baseline-Brine (TW) & 55.58 & - & 9.57 & - & 63.21 & - \\
\hline NPs only in $\mathrm{TW}^{1}$ & 67.19 & 11.61 & 31.98 & 22.41 & n.m. & n.m. \\
\hline Alkali (3000 ppm $\mathrm{Na}_{2} \mathrm{CO}_{3}$ ) in TW & 85.23 & 29.65 & 32.04 & 22.47 & n.m. & n.m. \\
\hline Alkali (7000 ppm Na$\left.{ }_{2} \mathrm{CO}_{3}\right)$ in TW & n.m. & n.m. & n.m. & n.m. & 74.48 & 11.27 \\
\hline NPs with 3000 ppm Na${ }_{2} \mathrm{CO}_{3}$ in TW & 71.67 & 16.09 & 55.86 & 46.29 & n.m. & n.m. \\
\hline Polymer (SNF 3630 S) in TW & n.m. & n.m. & n.m. & n.m. & 66.19 & 2.98 \\
\hline $\begin{array}{c}7000 \text { ppm Na} \mathrm{NaO}_{3} \text { with SNF } 3630 \mathrm{~S} \\
\text { in TW }\end{array}$ & n.m. & n.m. & n.m. & n.m. & 94.44 & 31.23 \\
\hline
\end{tabular}

n.m. $=$ not measured $;{ }^{1}$ Average of two nanomaterials; R.O. $=$ recovered oil; I.O. $=$ incremental oil (corrected to brine recovery).

\subsection{Two-Phase Corefloods}

A summary of the selected experiments is presented in Table 8, mainly for Berea and Bentheimer (Nordhorn). Results of the contact angle and Amott spontaneous imbibition experiments confirmed the potential of Keuper for ANP flooding; therefore, further investigations focused on the Bentheimer and Berea core plugs to conclude the potential of ANP flood. Only experiments using high-TAN oil were performed in the two-phase corefloods. The highest incremental recoveries were obtained with solution depicting the lowest equilibrium IFT. For evaluations performed using nanomaterials, additional experiments are required to draw better conclusions. Combining nanomaterials with alkali did not lead to substantial additional recovery, as compared with the effects induced by the alkali. In general, incremental recoveries obtained during the Amott imbibition evaluations differed from those in corefloods. We observed a good synergistic approach using the alkali and polymer as one single slug. This is in line with the results extensively reported by Schumi et al. [44]. 
Table 8. Summary of selected core flood data for the fluids used in this study. Data shown here are for experiments performed in high-TAN oil only.

\begin{tabular}{|c|c|c|c|c|c|}
\hline \multirow[b]{2}{*}{ Injected Fluid } & \multirow{2}{*}{$\begin{array}{c}\text { Equilibrium IFT } \\
\text { High TAN, } \\
{[\mathrm{mN} / \mathrm{m}]}\end{array}$} & \multicolumn{2}{|c|}{ Berea } & \multicolumn{2}{|c|}{ Nordhorn (Bentheimer) } \\
\hline & & $\begin{array}{l}\text { Incremental } \\
\text { Recovery } \%\end{array}$ & Injected PV & $\begin{array}{l}\text { Incremental } \\
\text { Recovery } \%\end{array}$ & Injected PV \\
\hline NPs only in TW ${ }^{1}$ & 3.75 & 3.90 & 2.00 & n.p. & n.p. \\
\hline Alkali (3000 $\mathrm{ppm} \mathrm{Na}_{2} \mathrm{CO}_{3}$ ) in TW & 0.11 & 14.00 & 2.00 & 12.00 & 1.5 \\
\hline Alkali $\left(7000 \mathrm{ppm} \mathrm{Na} \mathrm{CO}_{3}\right)$ in TW & 0.07 & n.p. & n.p. & 19.00 & 1.5 \\
\hline NPs with 3000 ppm $\mathrm{Na}_{2} \mathrm{CO}_{3}$ in TW & 0.095 & 18.00 & 2.00 & n.p. & n.p. \\
\hline Polymer (SNF 3630 S) in TW & 3.61 & 9.00 & 2.00 & 3.00 & 3.0 \\
\hline $\begin{array}{c}7000 \mathrm{ppm} \mathrm{Na} \mathrm{CO}_{3} \text { with SNF } 3630 \mathrm{~S} \\
\text { in TW }\end{array}$ & 0.04 & n.p. & n.p. & 29.00 & 2.00 \\
\hline
\end{tabular}

n.p. $=$ not performed; ${ }^{1}$ Average of two nanomaterials

Furthermore, comparing the data presented in Tables 6 and 8, Table 9 could be generated. We compared Amott imbibition data with those obtained from coreflooding in high-TAN oil. In the case of Berea, the incremental recoveries from alkali and nanoparticles combined with alkali are similar. Nanomaterials alone lead to different incremental recoveries, which appear to be explained by the nature of the reaction. Some studies report the use of huff-and-puff nanomaterial applications rather than EOR displacement. Interestingly, data obtained for the Nordhorn (Bentheimer) outcrops are very much comparable.

Table 9. Comparison of selected data between imbibition and coreflooding fluids in this study. Data shown here are for experiments performed with high-TAN oil only.

\begin{tabular}{|c|c|c|c|c|c|}
\hline \multirow{2}{*}{ Injected Fluid } & \multirow{2}{*}{$\begin{array}{c}\text { Equilibrium IFT } \\
\text { High TAN, } \\
{[\mathrm{mN} / \mathrm{m}]}\end{array}$} & \multicolumn{2}{|c|}{ Berea, Incremental Oil [\%] } & \multicolumn{2}{|c|}{$\begin{array}{c}\text { Nordhorn (Bentheimer), Berea, } \\
\text { Incremental Oil [\%] }\end{array}$} \\
\hline & & Imbibition & Flooding & Imbibition & Flooding \\
\hline NPs only in TW ${ }^{1}$ & 3.75 & 13.77 & 3.90 & n.m. & n.p. \\
\hline Alkali (3000 ppm Na $2 \mathrm{CO}_{3}$ ) in TW & 0.11 & 13.90 & 14.00 & n.m. & 12.00 \\
\hline Alkali (7000 ppm $\left.\mathrm{Na}_{2} \mathrm{CO}_{3}\right)$ in TW & 0.07 & n.m. & n.p. & 11.27 & 19.00 \\
\hline NPs with 3000 ppm Na${ }_{2} \mathrm{CO}_{3}$ in TW & 0.095 & 25.69 & 18.00 & n.m. & n.p. \\
\hline Polymer (SNF 3630 S) in TW & 3.61 & n.m. & 9.00 & 2.98 & 3.00 \\
\hline $\begin{array}{c}7000 \text { ppm Na} \mathrm{NaO}_{3} \text { with SNF } 3630 \mathrm{~S} \\
\text { in TW }\end{array}$ & 0.04 & n.m. & n.p. & 31.23 & 29.00 \\
\hline
\end{tabular}

n.p. = not performed; n.m. = not measured; ${ }^{1}$ Average of two nanomaterials.

By observing the changes in recovery from Figure 2 to Figure 4, one could argue that there are significant changes. The spontaneous imbibition tests demonstrated the significant impact of the various chemical cocktails on oil recovery. We used Amott cells to assess which chemical cocktail has the potential to significantly improve oil recovery by changing the interfacial tension and wettability. The two-phase tests confirm the selection of the chemical cocktail based on the Amott cells, as presented in Table 9. We performed bump-flooding at the end of the waterflooding; hence, the base case waterflooding was close to residual oil saturation. The incremental oil and remaining oil saturation accordingly were close to residual oil saturation. Regarding water saturation, the impact of the chemical cocktails was not fully tested. This is because they would be injected into an already water-flooded reservoir.

In addition, the role of capillary pressure was explored in this study. The Amott cell tests showed the interplay of capillary pressure and gravity. In terms of capillary pressure, 
there was wettability concerning real crude oil and interfacial tension. We observed the most significant changes in using chemical agents in oil-wet-prone Keuper core wettability changes, as opposed to Berea and Nordhorn cores. These mostly exhibited water-wet behavior; therefore, their recoveries and recovery rates were mostly influenced by the interplay between capillary pressure (manipulated by changing the IFT) and gravity forces (kept mostly constant for all experiments). Therefore, we manipulated the capillary pressure and imbibition rate by changing the IFT and wettability.

\subsection{Data Modeling}

Figure 5 shows the inverse bond number plotted against ultimate recovery for data for the evaluations performed in this study. Data are compared with those presented by Schechter et al. [48] and Babadagli [52] for sandstone samples. As an overall observation, the inverse bond number (NB-1) decreases with the decreasing IFT of the imbibing fluid. In that case, gravity drive contributes to the recovery. Thus, some observations can be identified for each outcrop samples type:

- Berea: This outcrop exhibited general water-wet behavior and the data showed more consistency, even for the lower inverse bond numbers. As reported by Saleh et al. [49] and Neubauer et al. [46], nanomaterial usage indicates a change in wettability as one of the EOR mechanisms. However, the inverse bond number evaluation revealed that a significant amount of additional recovery results from improving the gravity drive by lowering the inverse bond number;

- Keuper: Data presented here fall within the general trend; the data tend to scatter at lower inverse bond numbers for oil-wet Keuper cores. We attribute this behavior to the change in wettability along with lowering of IFT. Moreover, we observed that once inverse bond number increased for baseline experiments, oil recovery dropped, which is in agreement with Schechter et al. [48]. The high standard deviation is attributed to Keuper core heterogeneity;

- Nordhorn (Bentheimer): The curve depicts the highest recovery values for this outcrop type. The general trend is followed, because once the inverse bond number decreases, the ultimate recovery drops.

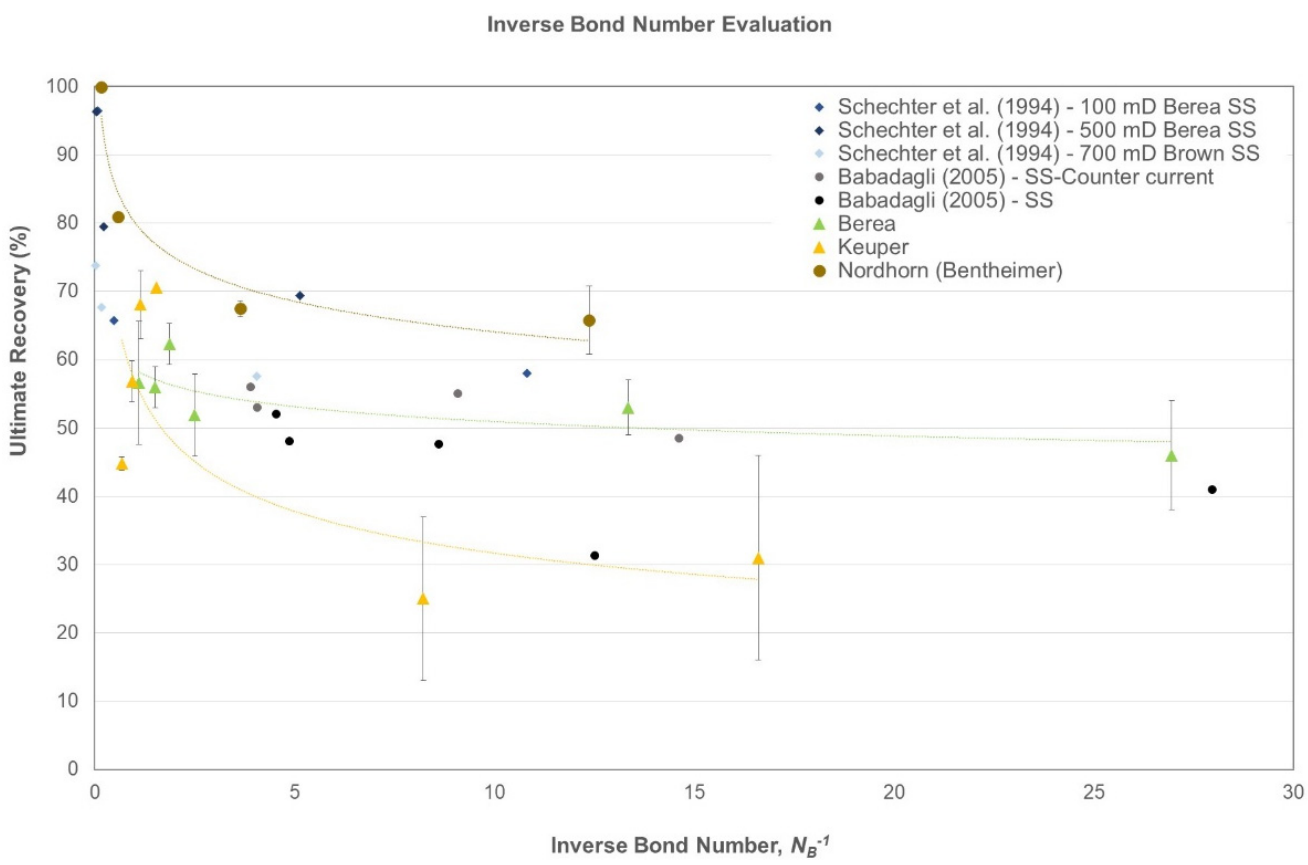

Figure 5. Ultimate recovery vs. inverse bond number as a modeling approach for the data presented in this study. 


\subsection{Porosity and Permeability Changes}

A comparison of the permeability and porosity before and after imbibition tests is shown in Table 10. Data are presented for the experiments performed in high-TAN oil mainly because the results for low-TAN oil were similar. A minimal reduction was observed after imbibition with the fluids tested here. In the case of nanomaterials, we assume that possible nanoparticle deposition is not linked to porosity reductions in the cases presented here.

Table 10. Summary comparison of porosity and permeability before and after Amott imbibition experiments. Data shown here are for experiments performed in high-TAN oil only.

\begin{tabular}{|c|c|c|c|c|c|c|c|}
\hline \multirow{2}{*}{ Imbibing Fluid } & \multirow{2}{*}{ Outcrop } & \multicolumn{3}{|c|}{ Porosity $\Phi,[\%]$} & \multicolumn{3}{|c|}{ Permeability, [mD] } \\
\hline & & Before & After & Diff. (\%) & Before & After & Diff. (\%) \\
\hline \multirow{2}{*}{ NPs only in TW ${ }^{1}$} & Berea & 22.60 & 21.34 & -1.83 & 477.62 & 419.82 & -12.14 \\
\hline & Keuper & 23.49 & 23.17 & 3.57 & 1381.62 & 1311.50 & -5.17 \\
\hline \multirow{3}{*}{ Alkali (3000 ppm Na $\mathrm{CO}_{3}$ ) in TW } & Berea & 22.58 & 22.12 & -2.04 & 399.55 & 364.44 & -8.82 \\
\hline & Keuper & 24.09 & 23.99 & -1.10 & 1238.83 & 1225.16 & -1.10 \\
\hline & Nord. (Bent) & 23.30 & 23.05 & -1.07 & 2343.05 & 2340.02 & -0.15 \\
\hline Alkali (7000 ppm Na${ }_{2} \mathrm{CO}_{3}$ ) in TW & Nord. (Bent) & 24.30 & 24.10 & -0.90 & 2448.62 & 2389.78 & -2.40 \\
\hline \multirow{2}{*}{ NPs with 3000 ppm $\mathrm{Na}_{2} \mathrm{CO}_{3}$ in TW } & Berea & 22.42 & 22.23 & -0.77 & 442.05 & 391.859 & -11.32 \\
\hline & Keuper & 24.28 & 23.69 & -2.63 & 1446.37 & 1320.94 & -8.03 \\
\hline Polymer (SNF 3630 S) in TW & Nord. (Bent) & 24.19 & 24.08 & 0.61 & 2346.49 & 2273.49 & -3.11 \\
\hline $\begin{array}{c}7000 \text { ppm Na} \mathrm{NaO}_{3} \text { with SNF } 3630 \mathrm{~S} \\
\text { in TW }\end{array}$ & Nord. (Bent) & 23.98 & 24.45 & 1.95 & 2310.33 & 2113.95 & -8.50 \\
\hline
\end{tabular}

n.p. = not performed; ${ }^{1}$ Average of two nanomaterials.

Permeability data also showed some minimal reduction with the tested fluids. Neubauer et al. [46] reported that permeability reduction is more pronounced in Berea outcrop cores as opposed to Keuper cores. Overall, we preliminary conclude that permeability reductions are not associated with the tested nanoparticles present in solution or other fluids. Preliminary analyses such as scanning electron microscopy (SEM) do not depict strong changes.

Notably, we have also investigated the possible effects in the case of nanomaterials in single-phase environment. Arguably, the nanoparticles used here could cause blockages or permeability reductions due to sorption. In our study, Scheurer et al. [78], core flood experiments showed that the injected nanofluids did not have a sufficient effect on permeability.

\section{Summary and Conclusions}

We have identified the conditions leading to increases in recovery rates as well as ultimate recovery by the imbibition of alkali, nanoparticles and polymer aqueous phases. The data obtained demonstrate how the oil TAN number (low and high TAN number) and type of chemical agent influence fluid-fluid and rock-fluid interactions.

The use of alkali or alkali together with nanomaterial in high-TAN oil resulted in a low-equilibrium IFT. It appears that alkali alone falls short of mobilizing trapped lowTAN oil in Keuper cases. Alkali-polymer is efficient in wettability alterations of oil-wet core plugs towards water-wet states for high-TAN oil. The investigated nanomaterials managed to restore a water-wet state in cores with high clay along with improving the gravity-driven flow.

When comparing porosity and permeability before and after imbibition, a slight reduction was observed after imbibition with brine and nanomaterials. We preliminary 
conclude that permeability reduction is not associated with the tested nanoparticles present in solution. We observed evidence of changes in the imbibition mechanism from countercurrent (capillary driven/high inverse bond number) to co-current (gravity-driven/low inverse bond number) for nanoparticles/alkali. The calculated inverse bond number correlates with the ultimate recovery, with a larger inverse bond number leading to lower ultimate recovery.

Overall, we have presented novel data on the synergy of IFT, contact angles, Amott imbibition and coreflooding for the chemical processes studied. We have leveraged from complementary laboratory techniques to define a comprehensive workflow that develops the understanding of wettability-alterations when injecting alkali, nanoparticles and polymers, or a combination thereof. The obtained results show that the workflow can be used as an efficient screening tool to determine the effectiveness of various substances to increase the oil recovery rate and ultimate recovery.

Author Contributions: R.E.H. worked on experimental evaluation, data interpretation, and writing. E.N. worked on the conceptualization of experiments, approaches, and project management. A.B., M.T., S.S., V.A. and M.B. worked on the experimental conceptualization, data interpretation, and provided technical support. T.C. provided support with technical expertise, advisory, and review. All authors have read and agreed to the published version of the manuscript.

Funding: This research received no external funding.

Institutional Review Board Statement: Not applicable.

Informed Consent Statement: Not applicable.

Data Availability Statement: Not applicable.

Acknowledgments: The authors would like to thank OMV E\&P GmbH for granting permission to publish this paper. Further thanks to Lorenz Triebnigg and Lobel Zvonimir Danicic from Montan University of Leoben for supporting on processing and compiling the final data.

Conflicts of Interest: The authors declare no conflict of interest.

\section{References}

1. Arekhov, V.; Hincapie, R.E.; Clemens, T.; Tahir, M. Variations in Wettability and Interfacial Tension during Alkali-Polymer Application for High and Low TAN Oils. Polymers 2020, 12, 2241. [CrossRef]

2. Sheng, J.J. Modern Chemical Enhanced Oil Recovery; Gulf Professional Publishing: Boston, MA, USA, 2011; p. 4. [CrossRef]

3. Al-Saedi, H.N.; Flori, R.E.; Al-Jaberi, S.K. Eliminate the role of clay in sandstone: EOR low salinity water flooding. J. Pet. Explor. Prod. Technol. 2019, 9, 1475-1483. [CrossRef]

4. Havre, T.E.; Sjöblom, J. Emulsion stabilization by means of combined surfactant multilayer (D-phase) and asphaltene particles. Colloids Surf. A Physicochem. Eng. Asp. 2003, 228, 131-142. [CrossRef]

5. Horváth-Szabó, G.; Czarnecki, J.; Masliyah, J. Liquid crystals in aqueous solutions of sodium naphthenates. J. Colloid Interface Sci. 2001, 236, 233-241. [CrossRef] [PubMed]

6. Mohamed, M.I.; Alvarado, V. Smart water flooding in berea sandstone at low temperature: Is wettability alteration the sole mechanism at play? In Proceedings of the SPE Annual Technical Conference and Exhibition, San Antonio, TX, USA, 9-11 October 2017. [CrossRef]

7. Sullivan, A.P.; Zaki, N.N.; Sjöblom, J.; Kilpatrick, P.K. The stability of water-in-crude and model oil emulsions. Can. J. Chem. Eng. 2008, 85, 793-807. [CrossRef]

8. Tahir, M.; Hincapie, R.E.; Langanke, N.; Ganzer, L.; Jaeger, P. Coupling microfluidics data with core flooding experiments to understand sulfonated/polymer water injection. Polymers 2020, 12, 1227. [CrossRef] [PubMed]

9. Bagci, S.; Kok, M.V.; Turksoy, U. Effect of brine composition on oil recovery by waterflooding. Pet. Sci. Technol. 2001, 19, 359-372. [CrossRef]

10. Bidhendi, M.M.; Garcia-Olvera, G.; Morin, B.; Oakey, J.S.; Alvarado, V. Interfacial viscoelasticity of crude oil/brine: An alternative enhanced-oil-recovery mechanism in smart waterflooding. SPE J. 2018, 23, 803-818. [CrossRef]

11. Ligthelm, D.J.; Gronsveld, J.; Hofman, J.; Brussee, N.; Marcelis, F.; van der Linde, H. Novel waterflooding strategy by manipulation of injection brine composition. In Proceedings of the EUROPEC/EAGE Conference and Exhibition, Society of Petroleum Engineers, Amsterdam, The Netherlands, 8-11 June 2009. [CrossRef]

12. Morrow, N.; Buckley, J. Improved oil recovery by low-salinity waterflooding. J. Pet. Technol. 2011, 63, 106-112. [CrossRef]

13. Shaker Shiran, B.; Skauge, A. Wettability and oil recovery by low salinity injection. In Proceedings of the SPE EOR Conference at Oil and Gas West Asia, Society of Petroleum Engineers, Muscat, Oman, 16-18 April 2012. [CrossRef] 
14. Webb, K.J.; Black, C.J.J.; Tjetland, G. A laboratory study investigating methods for improving oil recovery in carbonates. In Proceedings of the International Petroleum Technology Conference, Doha, Qatar, 21-23 November 2005. [CrossRef]

15. Du, D.; Pu, W.; Jin, F.; Hou, D.-D.; Shi, L. Experimental investigation on plugging and transport characteristics of pore-scale microspheres in heterogeneous porous media for enhanced oil recovery. J. Dispers. Sci. Technol. 2021, 42, 1152-1162. [CrossRef]

16. Sabooniha, E.; Rokhforouz, M.-R.; Ayatollahi, S. Pore-scale investigation of selective plugging mechanism in immiscible two-phase flow using phase-field method. Oil Gas Sci. Technol. Rev. IFP Energies Nouv. 2019, 74, 78. [CrossRef]

17. Delamaide, E.; Zaitoun, A.; Renard, G.; Tabary, R. Pelican lake field: First successful application of polymer flooding in a heavy oil reservoir. In Proceedings of the SPE Enhanced Oil Recovery Conference, Kuala Lumpur, Malaysia, 2-4 July 2013. [CrossRef]

18. Zhu, Y. Current developments and remaining challenges of chemical flooding EOR techniques in China. In Proceedings of the SPE Enhanced Oil Recovery Conference, Kuala Lumpur, Malaysia, 11-13 August 2015. [CrossRef]

19. Kumar, P.; Raj, R.; Koduru, N.; Kumar, S.; Pandey, A. Field implementation of mangala polymer flood: Initial challenges, mitigation and management. In Proceedings of the SPE EOR Conference at Oil and Gas West Asia, Muscat, Oman, 21-23 March 2016. [CrossRef]

20. Anand, A.; Al Sulaimani, H.; Riyami, O.; AlKindi, A. Success and challenges in ongoing field scale polymer flood in sultanate of Oman-A holistic reservoir simulation case study for polymer flood performance analysis \& prediction. In Proceedings of the SPE EOR Conference at Oil and Gas West Asia, Muscat, Oman, 26-28 March 2018. [CrossRef]

21. Sieberer, M.; Clemens, T.; Peisker, J.; Ofori, S. Polymer-flood field implementation: Pattern configuration and horizontal vs vertical wells. SPE Reserv. Eval. Eng. 2019, 22, 577-596. [CrossRef]

22. Watson, A.; Trahan, G.A.; Sorensen, W. An interim case study of an alkali-surfactant-polymer flood in the mooney field, Alberta, Canada. In Proceedings of the SPE Improved Oil Recovery Symposium, Tulsa, OK, USA, 12-16 April 2014. [CrossRef]

23. Yin, S.; Pu, H.; Zhou, S. An update on full field implementation of chemical flooding in Daqing Oilfield, China, and its future. In Proceedings of the SPE Improved Oil Recovery Conference, Tulsa, OK, USA, 14-18 April 2018. [CrossRef]

24. Pitts, M.; Dean, E.; Wyatt, K.; Skeans, E.; Deo, D.; Galipeault, A.; Moohagen, D.; Humphry, C. Instow a full field, multi-patterned alkali-surfactant-polymer flood-Analysis and comparison of phases 1 and 2. In Proceedings of the SPE Improved Oil Recovery Conference, Tulsa, OK, USA, 18-22 April 2020. [CrossRef]

25. Delamaide, E. Is chemical EOR finally coming of age? In Proceedings of the SPE Asia Pacific Oil \& Gas Conference and Exhibition, Virtual, 17-19 November 2020. [CrossRef]

26. Rock, A.; Hincapie, R.E.; Tahir, M.; Langanke, N.; Ganzer, L. On the role of polymer viscoelasticity in enhanced oil recovery: Extensive laboratory data and review. Polymers 2020, 12, 2276. [CrossRef]

27. Sheng, J.; Leonhardt, B.; Al Azri, N.S. Status of polymer-flooding technology. J. Can. Pet. Technol. 2015, 54, 116-126. [CrossRef]

28. Hincapie, R.E. Pore-Scale Investigation of the Viscoelastic Phenomenon during Enhanced Oil Recovery (EOR) Polymer Flooding through Porous Media; Papierflieger: Clausthal-Zellerfeld, Germany, 2016; ISBN 978-3-86948-531-7.

29. Hashmet, M.R.; Qaiser, Y.; Mathew, E.S.; AlAmeri, W.; AlSumaiti, A. Injection of polymer for improved sweep efficiency in high temperature high salinity carbonate reservoirs: Linear X-ray aided flood front monitoring. In Proceedings of the SPE Kingdom of Saudi Arabia Annual Technical Symposium and Exhibition, Dammam, Saudi Arabia, 24-27 April 2017. [CrossRef]

30. Castro-García, R.H.; Maya-Toro, G.A.; Jimenez-Diaz, R.; Quintero-Perez, H.I.; Díaz-Guardia, V.M.; Colmenares-Vargas, K.M.; Palma-Bustamante, J.M.; Delgadillo-Aya, C.L.; Pérez-Romero, R.A. Polymer flooding to improve volumetric sweep efficiency in waterflooding processes. CTEF Cienc. Tecnol. Futuro 2019, 6, 71-90.

31. Al-Bahar, M.A.; Merrill, R.; Peake, W.; Jumaa, M.; Oskui, R. Evaluation of IOR potential within Kuwait. In Proceedings of the Abu Dhabi International Conference and Exhibition, Abu Dhabi, United Arab Emirates, 10-13 October 2004. [CrossRef]

32. Berret, J.-F.; Yokota, K.; Morvan, M. Interactions between polymers and nanoparticles: Formation of "Supermicellar" hybrid aggregates. Soft Mater. 2004, 2, 71-84. [CrossRef]

33. Choi, S.K.; Son, H.A.; Kim, H.T.; Kim, J.W. Nanofluid enhanced oil recovery using hydrophobically associative zwitterionic polymer-coated silica nanoparticles. Energy Fuels 2017, 31, 7777-7782. [CrossRef]

34. Galas, C.; Clements, A.; Jaafar, E.; Jeje, O.; Holst, D.; Holst, R.; Limited, S.A. Identification of Enhanced Oil Recovery Potential in Alberta: Phase 2 Final Report for Energy Resources Conservation Board; Sproule Associated Limited: Ottawa, ON, Canada, 2012.

35. Maurya, N.; Mandal, A. Studies on behavior of suspension of silica nanoparticle in aqueous polyacrylamide solution for application in enhanced oil recovery. Pet. Sci. Technol. 2016, 34, 429-436. [CrossRef]

36. Pitts, M.J.; Wyatt, K.; Surkalo, H. Alkaline-polymer flooding of the David Pool, Lloydminster Alberta. In Proceedings of the SPE/DOE Symposium on Improved Oil Recovery, Tulsa, OK, USA, 17-21 April 2004. [CrossRef]

37. Wu, Y.; Dong, M.; Shirif, E. Study of Alkaline/Polymer Flooding for Heavy-Oil Recovery Using Channeled Sandpacks. SPE Reserv. Eval. Eng. 2011, 14, 310-319. [CrossRef]

38. Clarke, A.; Howe, A.M.; Mitchell, J.; Staniland, J.; Hawkes, L.A. How viscoelastic polymer flooding enhances displacement efficiency. In Proceedings of the SPE Asia Pacific Enhanced Oil Recovery Conference, Society of Petroleum Engineers, Kuala Lumpur, Malaysia, 11-13 August 2015. [CrossRef]

39. Clarke, A.; Howe, A.M.; Mitchell, J.; Staniland, J.; Hawkes, L.; Leeper, K. Mechanism of anomalously increased oil displacement with aqueous viscoelastic polymer solutions. Soft Matter 2015, 11, 3536-3541. [CrossRef] 
40. Hincapie, R.E.; Rock, A.; Wegner, J.; Ganzer, L. Oil mobilization by viscoelastic flow instabilities effects during polymer EOR: A pore-scale visualization approach. In Proceedings of the SPE Latin America and Caribbean Petroleum Engineering Conference, Society of Petroleum Engineers, Buenos Aires, Argentina, 17-19 May 2017. [CrossRef]

41. Sheng, J. Critical review of alkaline-polymer flooding. J. Pet. Explor. Prod. Technol. 2016, 7, 147-153. [CrossRef]

42. Wang, D.; Wang, G.; Xia, H. Large scale high visco-elastic fluid flooding in the field achieves high recoveries. In Proceedings of the SPE Enhanced Oil Recovery Conference, Society of Petroleum Engineers, Kuala Lumpur, Malaysia, 19-20 July 2011. [CrossRef]

43. Yin, D.; Zhao, N.; Gao, J.; Gai, J. Experimental study of enhancing oil recovery with weak base alkaline/surfactant/polymer. Int. J. Polym. Sci. 2017, 2017, 4652181. [CrossRef]

44. Schumi, B.; Clemens, T.; Wegner, J.; Ganzer, L.; Kaiser, A.; Hincapie, R.E.; Leitenmueller, V. Alkali/cosolvent/polymer flooding of high-TAN oil: Using phase experiments, micromodels, and corefloods for injection-agent selection. SPE Reserv. Eval. Eng. 2020, 23, 463-478. [CrossRef]

45. ShamsiJazeyi, H.; Miller, C.A.; Wong, M.S.; Tour, J.M.; Verduzco, R. Polymer-coated nanoparticles for enhanced oil recovery. J. Appl. Polym. Sci. 2014, 131, 15. [CrossRef]

46. Neubauer, E.; Hincapie, R.E.; Borovina, A.; Biernat, M.; Clemens, T.; Ahmad, Y.K. Influence of nanofluids on wettability changes and interfacial tension reduction. In Proceedings of the SPE Europec, Virtual, 1-3 December 2020.

47. Neubauer, E.; Hincapie, R.E.; Clemens, T.; Maximilian, C. Selection of nanomaterials as emulsion stabilizers in alkali-polymer EOR of high-TAN number oil. In Proceedings of the SPE Improved Oil Recovery Conference, Virtual, 31 August-4 September 2020.

48. Schechter, D.; Zhou, D.; Orr, F. Low IFT drainage and imbibition. J. Pet. Sci. Eng. 1994, 11, 283-300. [CrossRef]

49. Saleh, S.; Neubauer, E.; Borovina, A.; Hincapie, R.E.; Clemens, T.; Ness, D. Wettability changes due to nanomaterials and alkali-A proposed formulation for EOR. Nanomaterials 2021, 11, 2351. [CrossRef]

50. Sharma, M.; Jang, L.; Yen, T. Transient interfacial tension behavior of crude-oil/caustic interfaces. SPE Reserv. Eng. 1989, 4, 228-236. [CrossRef]

51. Al-Quraishi, A.A. Oil Recovery by Dynamic Imbibition in Low Tension Aqueous Systems. Oil Gas Sci. Technol. Rev. IFP Energies Nouv. 2004, 59, 267-273. [CrossRef]

52. Babadagli, T. Analysis of oil recovery by spontaneous imbibition of surfactant solution. Oil Gas Sci. Technol. Rev. IFP Energies Nouv. 2005, 60, 697-710. [CrossRef]

53. Kamal, M.S.; Adewunmi, A.A.; Sultan, A.S.; Al-Hamad, M.F.; Mehmood, U. Recent advances in nanoparticles enhanced oil recovery: Rheology, interfacial tension, oil recovery, and wettability alteration. J. Nanomater. 2017, 2017, e2473175. [CrossRef]

54. Ershadi, M.; Alaei, M.; Rashidi, A.; Ramazani, A.; Khosravani, S. Carbonate and sandstone reservoirs wettability improvement without using surfactants for chemical enhanced oil recovery (C-EOR). Fuel 2015, 153, 408-415. [CrossRef]

55. Bayat, A.E.; Junin, R.; Samsuri, A.; Piroozian, A.; Hokmabadi, M. Impact of Metal Oxide Nanoparticles on Enhanced Oil Recovery from Limestone Media at Several Temperatures. Energy Fuels 2014, 28, 6255-6266. [CrossRef]

56. Joonaki, E.; Ghanaatian, S. The application of nanofluids for enhanced oil recovery: Effects on interfacial tension and coreflooding process. Pet. Sci. Technol. 2014, 32, 2599-2607. [CrossRef]

57. Ma, H.; Luo, M.; Dai, L.L. Influences of surfactant and nanoparticle assembly on effective interfacial tensions. Phys. Chem. Chem. Phys. 2008, 10, 2207-2213. [CrossRef] [PubMed]

58. Moradi, B.; Pourafshary, P.; Jalali, F.; Mohammadi, M.; Emadi, M. Experimental study of water-based nanofluid alternating gas injection as a novel enhanced oil-recovery method in oil-wet carbonate reservoirs. J. Nat. Gas Sci. Eng. 2015, 27, 64-73. [CrossRef]

59. Roustaei, A.; Bagherzadeh, H. Experimental investigation of $\mathrm{SiO}_{2}$ nanoparticles on enhanced oil recovery of carbonate reservoirs. J. Pet. Explor. Prod. Technol. 2015, 5, 27-33. [CrossRef]

60. Roustaei, A.; Saffarzadeh, S.; Mohammadi, M. An evaluation of modified silica nanoparticles' efficiency in enhancing oil recovery of light and intermediate oil reservoirs. Egypt. J. Pet. 2013, 22, 427-433. [CrossRef]

61. Esfandiarian, A.; Azdarpour, A.; Santos, R.M.; Mohammadian, E.; Hamidi, H.; Sedaghat, M.; Dehkordi, P.B. Mechanistic investigation of LSW/surfactant/alkali synergism for enhanced oil recovery: Fluid-fluid interactions. ACS Omega 2020, 5, 30059-30072. [CrossRef]

62. Auflem, I.H.; Westvik, A.; Sjöblom, J. Destabilization of water-in-crude oil emulsions based on recombined oil samples at various pressures. J. Dispers. Sci. Technol. 2003, 24, 103-112. [CrossRef]

63. Acevedo, S.; Borges, B.; Quintero, F.; Piscitelly, V.; Gutierrez, L.B. Asphaltenes and other natural surfactants from cerro negro crude oil. Stepwise adsorption at the water/toluene interface: Film formation and hydrophobic effects. Energy Fuels 2005, 19, 1948-1953. [CrossRef]

64. Czarnecki, J.; Moran, K. On the stabilization mechanism of water-in-oil emulsions in petroleum systems. Energy Fuels 2005, 19, 2074-2079. [CrossRef]

65. Verruto, V.J.; Kilpatrick, P.K. Water-in-model oil emulsions studied by small-angle neutron scattering: Interfacial film thickness and composition. Langmuir 2008, 24, 12807-12822. [CrossRef]

66. Elyaderani, S.M.G.; Jafari, A. Investigation of interactions between silica nanoparticle, alkaline, and polymer in micromodel flooding for enhanced oil recovery. Energy Sour. Part A Recover. Util. Environ. Eff. 2020, 1-18. [CrossRef]

67. Rueda, E.; Akarri, S.; Torsæter, O.; Moreno, R.B. Experimental investigation of the effect of adding nanoparticles to polymer flooding in water-wet micromodels. Nanomaterials 2020, 10, 1489. [CrossRef] 
68. Hu, Y.; Zhao, Z.; Dong, H.; Mikhailova, M.V.; Davarpanah, A. Hybrid application of nanoparticles and polymer in enhanced oil recovery processes. Polymers 2021, 13, 1414. [CrossRef] [PubMed]

69. Gbadamosi, A.O.; Junin, R.; Manan, M.A.; Agi, A.; Yusuff, A.S. An overview of chemical enhanced oil recovery: Recent advances and prospects. Int. Nano Lett. 2019, 9, 171-202. [CrossRef]

70. Ali, J.A.; Kolo, K.; Manshad, A.K.; Mohammadi, A.H. Recent advances in application of nanotechnology in chemical enhanced oil recovery: Effects of nanoparticles on wettability alteration, interfacial tension reduction, and flooding. Egypt. J. Pet. 2018, 27, 1371-1383. [CrossRef]

71. Cheraghian, G.; Rostami, S.; Afrand, M. Nanotechnology in enhanced oil recovery. Process. 2020, 8, 1073. [CrossRef]

72. Perez, H.I.Q.; Cañas, M.C.R.; Garcia, R.H.C.; Bohorquez, A.R.R. Use of nanoparticles to improve thermochemical resistance of synthetic polymer to enhanced oil recovery applications: A review. CTEF Cienc. Tecnol. Futuro 2020, 10, 85-97. [CrossRef]

73. Bila, A.; Torsæter, O. Experimental investigation of polymer-coated silica nanoparticles for EOR under harsh reservoir conditions of high temperature and salinity. Nanomaterials 2021, 11, 765. [CrossRef]

74. Mohnot, S.; Bae, J.; Foley, W. A Study of mineral/alkali reactions. SPE Reserv. Eng. 1987, 2, 653-663. [CrossRef]

75. Jiecheng, C.; Wanfu, Z.; Qingfuo, W.; Gang, C.; Wenguang, B.; Changming, Z.; Meie, L. Technical breakthrough in production engineering ensures economic development of ASP flooding in daqing oilfield. In Proceedings of the SPE Asia Pacific Oil \& Gas Conference and Exhibition, Adelaide, Australia, 14-16 October 2014. [CrossRef]

76. AlGeer, M.A.; Gmira, A.; Al-Enezi, S.M.; Yousef, A.A. A new insight on the impact of individual ions on fluid/fluid interactions and smart water recovery. In Proceedings of the SPE EOR Conference at Oil and Gas West Asia, Muscat, Oman, 21-23 March 2016

77. Tahir, M.; Hincapie, R.E.; Ganzer, L. Unlocking the effects of fluid optimization on remaining oil saturation for the combined sulfate-modified water and polymer flooding. Energies 2020, 13, 3049. [CrossRef]

78. Scheurer, C.; Hincapie, R.E.; Neubauer, E.; Metz, A.; Ness, D. Sorption of nanomaterials to sandstone rock. Nanomaterials 2022, 12, 200. [CrossRef] [PubMed] 